\title{
RESPON PERTUMBUHAN BIBIT PISANG MAS (Musa acuminate Linn) TERHADAP KOMPOSISI MEDIA TANAM DAN ZPT
}

\author{
Fuad Ardianto ${ }^{1)}$ dan Sutiah ${ }^{2)}$ \\ 1) Mahasiswa Prodi Agroteknologi, Fakultas Pertanian, Universitas Islam Balitar \\ 2) Dosen Prodi Agroteknologi, Fakultas Pertanian, Universitas Islam Balitar
}

\begin{abstract}
This research aims 1) to knowing interanction between the growing media and ZPT application to repayment bananas, 2) to knowing growing media composition best to repayment seeds banana, 3) to knowing best ZPT composition to repayment seeds bananas. This study was conducted using a randomized block design arranged in factorial (RAK). First factor that is med kind he $(M)$ with three levels and second faktor is ZPT concentration with three levels. The variables measured covers time emerging shoots, high plant, stem diameter, number leaves, long leaf, wide leaves, number root, long roots. Analysis of data using useanalysis variance (ANOVA). The level of 5\%. Result research show that no happen interaction between growing media composition and ZPT concentrationagains growth seeds bananas.
\end{abstract}

Keywords: growing media composition, concentration ZPT, growth seeds banana

\section{PENDAHULUAN}

Pisang mas (Musa acuminate Linn) merupakan salah satu jenis pisang yang digemari oleh masyarakat Indonesia. Selain memiliki kandungan vitamin dan karbohidrat, pisang mas (Musa acuminate Linn) juga dapat disajikan sebagai buah segar atau diolah menjadi produk makanan (Prabawati et al 2008). Umur panen tanaman pisang mas relatif singkat dari pada tanaman pisang lainnya, tanaman pisang mas dapat dipanen pada umur 11 bulan dan dapat menghasilkan 8 sampai $10 \mathrm{~kg}$ buah pisang dengan harga $\mathrm{Rp} 2.000-$ $5.000 \mathrm{ribu} / \mathrm{kg}$ atau berisi 7 sisir setiap tandannya dengan harga 1 sisir pisang bisa mencapai Rp 15.000 ribu (Bappeda Jatim 2013).

Menurut Badan Pusat Statistik (2014) tanaman pisang memiliki luas pertanaman dan produksi yang tinggi dibandingkan dengan komoditas buah lainnya. Jawa Timur merupakan sentra produksi pisang terbesar di Pulau Jawa, dengan produksi sebesar 1.336.685 ton atau hampir mencapai 19,48 persen.

Usaha tani pisang tidak lepas dari berbagai kendala, diantaranya kurangnya ketersediaan bibit pisang yang bermutu serta rendahnya kesadaran petani untuk penerapan teknologi yang tepat (Suharto at al 2012). Menurut Santoso J (2012) penggunaan anakan pisang dewasa memiliki kelebihan dari pada metode lain karena dianggap murah dan mudah dalam pelaksanaannya. Namun penggunaan anakan pisang dewasa memiliki beberapa kekurangan diantaranya membutuhkan banyak bibit karena anakan pisang dewasa hanya akan menjadi satu bibit, pengambilan anakan pisang dapat menganggu pertumbuhan tanaman utama serta adanya resiko penularan penyakit dari luka akibat pemotongan anakan. Mulyati et al (2008) menambahkan perbanyakan pisang 
menggunakan kultur jaringan dapat menghasilkan bibit pisang yang seragam dalam jumlah banyak serta dalam waktu yang lebih cepat. Namun penggunaan perbanyakan secara kultur jaringan relatif mahal di tinggkat petani.

Untuk menanggulangi kendala tersebut, menurut Mulyanti et al (2008) peningkatan produktifitas pisang dapat dilakukan diantaranya dengan cara penyediaan bibit yang baik, pemupukan dan perawatan, serta pengaturan jumlah anakan. Suharto et al (2012) menambahkan bibit yang baik dapat dihasilkan dari penyemaian bibit. Penyemaian bibit dimaksudkan untuk menghasilkan anakan pisang yang lebih banyak dan seragam, serta mencegahan serangan penyakit.

Penggunaan bibit yang berasal dari bonggol (bit) dapat menjadi altrnatif dalam penyediaan bibit. Santoso J (2012) mengatakan metode belah bongol bit merupakan perbanyakan dengan memanfaatkan mata tunas dari bongol tanaman pisang yang dibelah sesuai dengan mata tunasnya. Cara ini dikatakan dapat menghasilkan bibit yang seragam dalam jumlah banyak. Biaya yang relative murah karena memanfaatkan bonggol sisa tebangan. Kekurangan metode belah bonggol (bit) adalah bonggol yang sering gagal tumbuh tunas karena lamanya pembentukan akar dan kuncup lateral disebabkan kulit bonggol yang tebal.

Asmarawati M dan Ahmad B (2011) Mengatakan bibit pisang menghendaki media tanam dengan struktur remah dengan keseimbangan perbandingan bahan padat dan ruang berpori. Pemberian kompos pada tanah dapat memperbaiki struktur tanah serta sifat fisik dan kimia tanah. Penambahan pasir pada tanah dapat menciptakan keseimbangan bahan padat dan ruang berpori pada tanah.

Pertumbuhan pada akar dipengaruhi oleh hormon auksin yang dikandung dalam akar dan ditranslokasikan ke akar untuk mendorong pertumbuhan akar tanaman (Rineksane 2005). Pamungkas S (2008), menambahkan auksin pada tanaman berperan dalam merangsang pertumbuhan kalus, pembesaran sel dan pertumbuhan akar, serta morfogenesis terutama berinteraksi dengan sitokinin.Tujuan penelitian ini yaitu: 1) untuk mengetahui apakah terdapat interaksi antara media tanam dan aplikasi ZPT terhadap pertunasan pisang, 2) untuk mengetahui komposisi media tanam terbaik terhadap pertunasan bibit pisang, 3) untuk mengetahui komposisi ZPT terbaik terhadap pertunasan bibit pisang.

\section{METODE PENELITIAN}

\section{Tempat dan Waktu Penelitian}

Penelitian dilakukan di Desa Pasiraman Kecamatan Wonotirto Kabupaten Blitar dengan ketinggian tempat kurang lebih $850 \mathrm{dpl}$. Penelitian dilaksanakan dari bulan Mei sampai Juli 2017.

\section{Rancangan Penelitian}

Penelitian ini menggunakan Rancangan Acak Kelompok (RAK) dengan pola faktorial, yang terdiri 2 faktor. Faktor pertama ialah jenis media (M) dengan tiga level yaitu :

M1 = media campuran tanah : pasir : pupuk kompos ( $2: 1: 1)$

M2 = media campuran tanah $:$ pasir $:$ pupuk kompos $(2: 1: 2)$

M3 = media campuran tanah $:$ pasir $:$ pupuk kompos $(2: 2: 1)$

Faktor kedua ialah konsentrasi ZPT dengan tiga level yaitu : 
$\mathrm{Z1}=1.5 \mathrm{ml}$ liter

$\mathrm{Z} 2=2 \mathrm{ml}$ liter

$\mathrm{Z} 3=2.5 \mathrm{ml}$ liter

Kombinasi dari kedua faktor tersebut diperoleh 9 kombinasi, yang diulang sebanyak tiga kali sehingga diperoleh 27 plot penelitian. Area dibagi menjadi 3 kelompok, masing - masing kelompok terdiri dari 9 plot penelitian dan setiap plot berisi 5 tanaman, jumlah total tanaman sebanyak 135 tanaman.

Variabel yang diamati meliputi waktu muncul tunas, tinggi tanaman, diameter batang, jumlah daun, panjang daun, lebar daun, jumlah akar, panjang akar. Data akan dianalisis menggunakan sidik ragam (uji F) pada taraf nyata 5\%, apabila hasil sidik ragam berpengaruh nyata maka akan dilanjutkan uji Duncan's Multiple Range Test (DMRT) pada taraf 5\%, apa bila tidak berpengaruh nyata maka dilanjutkan dengan uji Regresi.

Pelaksanaan penelitian meliputi persiapan bibit, persiapan media tanam, pemberian zpt pada bibit, penanaman, pemeliharaan bibit dan pencabutan bibit (panen).

Bonggol yang dipakai merupakan bonggol anakan pedang yang diambil dari tanaman yang sehat, tidak terserang penyakit dan tidak busuk baik bonggol dan batangnya. Bonggol diambil dari tanah menggunakan linggis dan canggkul secara hati hati agar tidak merusak mata tunas.

Bersihkan bonggol dari tanah dan akar yang menempel, kemudian dipotong dengan ukuran 10X10 $\mathrm{cm}$ berdasarkan jumlah mata tunas. Kemudian rendam potongan bonggol pisang dalam air yang telah diberi fungisida dengan dosis $2 \mathrm{gr} / \mathrm{lt}$, rendam potongan selama 15 menit kemudian tiriskan. Setelah itu rendam kembali potongan pisang kedalam ZPT antonik selama 1 jam sesuai dengan tingkatan konsentrasi penelitian yang diteliti. Mata tunas yang telah dipotong kemudian dikelompokkan berdasarkan umur mata tunas mulai dari muda, sedang dan tua.

Media yang dipakai adalah campuran dari tiga jenis media yaitu tanah, pasir, kompos. perbandingan media sesuai dengan perlakuaan yang diteliti. Penanaman dilakukan sore hari untuk mengurangi penguapan, tanam bonggol pada polybag dengan posisi tegak, kemudian diberi label sesuai dengan perlakuan. Polybag yang telah terisi bonggol kemudian dipindahkan pada tempat yang teduh. Pemeliharaan meliputi penyiraman, penyiangan, pengendalian hama dan penyakit.

\section{HASIL DAN PEMBAHASAN}

\section{Pengaruh Perlakuan Media dan ZPT}

Hasil analisis sidik ragam (ANOVA) taraf 5\% dengan Rancangan Acak Kelompok (RAK) menunjukkan bahwa tidak terdapat interaksi antara perlakuan komposisi media dan konsentrasi ZPT pada pembibitan tunas pisang. Perlakuan media hanya berpengaruh nyata pada waktu muncul tunas. Sedangkan perlakuan konsentrasi ZPT berpengaruh nyata pada perlakuan panjang akar. Hal ini diduga karena terdapat perbedaan cadangan makanan yang terdapat pada mata tunas dari belah bonggol. Pada umumnya perbedaan umur mata tunas akan berpengaruh terhadap kandungan karbohidrat dan protein sebagai cadangan makanan yang dikandung dalam mata tunas.

Hal ini sesuai dengan pendapat Sutopo (1992) dalam Magfoer (2009) bahwa cadangan makanan yang terdapat pada bahan tanaman akan sangat mempengaruhi pertumbuhan awal suatu tanaman. Cadangan makanan pada mata tunas berfungsi memberikan energi untuk embrio pada mata tunas untuk menjadi baru. Hal ini 
disebabkan Karena akar tanaman yang belum dapat menyerap unsur hara yang berada didalam tanah sehingga untuk menunjang pertumbuhan, tanaman akan merombak cadangan makanan menjadi bahan yang dapat diserap oleh tanaman. Perbedaan cadangan makan menyebabkan mata tunas yang memliki cadangan lebih banyak akan memiliki kemampuan untuk tumbuh lebih baik dari pada mata tunas yang memiliki cadangan makanan yang sedikit.

Menurut Sari (2009) mata tunas yang memiliki simpanan cadangan makanan yang berupa protein dan karbohidart akan mempengaruhi perkembangan pertumbuhan akar dan mata tunas. Rosalia (2016) menambahkan mata tunas muda memiliki cadangan karbohidrat yang rendah dan kandungan protein yang tinggi sedangkan mata tunas tua mengandung karbohidrat yang tinggi dengan kandungan protein yang rendah.

Kandungan karbohidrat pada mata tunas yang tinggi menyebabkan tunas lebih cepat berakar dari pada mata tunas dengan kandungan karbohidrat rendah. Bila kandungan karbohidrat pada mata tunas rendah maka akan memiliki kandungan protein yang lebih tinggi, mata tunas yang memiliki kandungan protein yang tinggi pertumbuhan mata tunasnya akan lebih cepat namun pertumbuhan akarnya akan terhambat sudomo (2007) dalam Magfoer et al (2009).

\section{Waktu Muncul Tunas}

Hasil analisis sidik ragam (ANOVA) taraf 5\% dengan Rancangan Acak Kelompok (RAK) menunjukkan bahwa interaksi antara komposisi media tanam (M) dengan konsentrasi Zat Pengatur Tumbuh (ZPT) tidak berpengaruh nyata pada variabel presentasi muncul tunas. Komposisi media tanaman (M) tidak memberikan pengaruh nyata pada variabel presentasi waktu muncul tunas. Konsentrasi ZPT (Z) berpengaruh nyata terhadap variabel presentasi muncul tunas.

Tabel 1. Pengaruh Komposisi Media Tanam (M) dan Konsentrasi Zat Pengatur Tumbuh (Z) Terhadap Presentasi Muncul Tunas.

Perlakuan

\section{Media (M)}

M1 ( tanah : pasir : kompos, 2:1:1)

M2 ( tanah : pasir : kompos, 2:1:2)

M3 (tanah : pasir : kompos, 2:2:1)

ZPT (Z)

$\mathrm{Z} 1(1.5 \mathrm{ml} / \mathrm{l})$

$63.07 \mathrm{a}$

$\mathrm{Z} 2(2 \mathrm{ml} / \mathrm{l})$

$92.59 \mathrm{~b}$

$\mathrm{Z} 3(2.5 \mathrm{ml} / \mathrm{l})$

$81.48 \mathrm{ab}$

Keterangan : Angka-angka yang diikuti dengan huruf yang sama pada baris dan kolom yang sama tidak berbeda nyata pada uji Duncan $(\alpha=0,05)$. 
Hasil uji DMRT 5\% (Tabel 1) menunjukkan bahwa perlakuan media tidak menunjukkan perbedaan yang nyata pada variabel presentasi muncul tunas. Perlakuan ZPT menunjukkan perbedaan yang nyata pada perlakuan Z2 $(2 \mathrm{ml} / \mathrm{l})$ dengan rata rata kemunculan tunas $92.59 \%$ namun tidak berbeda nyata dengan perlakuan Z3 $(2,5 \mathrm{ml} / \mathrm{l})$ dengan rata rata kemunculan tunas $81,48 \%$. Hal ini diduga karena pemberian ZPT atonik $2 \mathrm{ml} / \mathrm{l}$ air mengandung hormon auksin yang dapat menstimulasi pertumbuhan tunas bibit pisang.

Pamungkas (2008) mengatakan bahwa Zat pengatur tumbuh dapat menstimulasi pertumbuhan dengan memberikan isarat pada sel target untuk membelah atau memanjang. Auksin pada tanaman berperan dalam merangsang pertumbuhan kalus, pembesaran sel dan pertumbuhan akar, serta morfogenesis terutama berinteraksi dengan sitokinin. Suprapto (2004) menambahkan auksin sintetik yang terkandung pada atonik mendorong terjadinya pembelahan sel dengan cara mengurangi tekanan pada dinding sel karena membran plasma dinding sel menjadi longgar akibat pengaktifan pompa ion pada membrane plasma, sehingga air dapat mudah masuk ke dalam sel dan terjadi pembesaran dan perpanjangan sel.

Abidin dan Lontoh (1984) dalam Jati (2013) mengatakan Penerapan ZPT pada tanaman perlu memperhatikan konsentrasi untuk setiap jenis tanaman, sifat-sifat zat tumbuh yang digunakan serta cara pemberian ZPT pada tanaman agar memberikan respon pada tanaman seperti yang diharapkan. Rineksane (2005) menambahkan pada konsentrasi yang lebih tinggi auksin akan menghambat perpanjangan sel dengan memproduksi hormon yang berfungsi sebagai inhibitor pada perpanjangan sel, sedangkan konsentrasi yang terlalu rendah tidak efektif merangsang pembentukan akar (Rahayu dan Riendriasari, 2016).

Konsentrasi auksin optimum dalam merangsang pertumbuhan akar, kuncup dan daun mempunyai kisaran yang berbeda beda, biasanya pada konsentrasi tertentu antara 10-8 M sampai 10-4 M (Widiastoety, 2014).

Atonik salah satu hormon tumbuhan yang mengandung auksin sintetik. Sunarlim et al (2011) mengatakan kandungan dalam atonik berupa natrium orthophenol $(0,2 \%)$, natrium para nitrophenol $(0,3 \%)$, natrium 5-nitroguaiacolat $(0,1 \%)$, dan 2,4 dinitrophenolat $(0,01 \%)$. Pada dasarnya antonik berperan dalam merangsang pertumbuhan akar tanaman, meningkatan keluarnya kuncup, serta mengefektifkan penyerapan unsur hara (Sunarlim, et al 2011).

Seperti penelitien yang dilakukan oleh Asmarawati dan Ahmad, (2011) bahwa perlakuan perendaman belahan bonggol bit pisang dengan ZPT atonik memberikan pengaruh nyata pada variabel tinggi tanaman dibandingkan dengan perlakuan lainnya

Seperti penelitian yang dilakukan oleh Abdulrahman (2013) bahwa perlakuan perendaman pada atonik dengan konsentrai $2 \mathrm{ml} / \mathrm{l}$ air memberikan pengaruh nyata pada pertumbuhan dan hasil jagung semai.

\section{Tinggi Tanaman}

Hasil analisis sidik ragam (ANOVA) taraf 5\% dengan Rancangan Acak Kelompok (RAK) menunjukkan bahwa interaksi antara komposisi media tanam (M) dengan konsentrasi Zat Pengatur Tumbuh (ZPT) tidak berpengaruh nyata pada variabel tinggi tanaman pisang pada semua umur pengamatan . Komposisi media tanaman (M) tidak memberikan pengaruh nyata pada semua umur pengamatan, kecuali pada umur 
pengamatan $21 \mathrm{HST}$. Konsentrasi ZPT (Z) tidak berpengaruh nyata terhadap tinggi tanaman pisang pada semua umur pengamatan.

Hasil uji dmrt 5\% perlakuan komposisi media dan konsentrasi ZPT pada variabel tinggi tanaman disajikan pada Tabel 2.

Tabel 2. Pengaruh Komposisi Media Tanam (M) dan Konsentrasi Zat Pengatur Tumbuh (Z) Terhadap Tinggi Tanaman Pisang Pada Berbagai Umur Pengamatan.

\begin{tabular}{|c|c|c|c|c|c|c|c|c|}
\hline \multirow[b]{2}{*}{ Perlakuan } & \multicolumn{8}{|c|}{ Tinggi Tanaman (cm) } \\
\hline & HST & HST & $28 \mathrm{HST}$ & $35 \mathrm{HST}$ & $42 \mathrm{HST}$ & $49 \mathrm{HST}$ & $56 \mathrm{HST}$ & $63 \mathrm{HST}$ \\
\hline \\
\hline $\begin{array}{l}\text { M1(tanah : } \\
\text { pasir : kompos, } \\
\text { 2:1:1) } \\
\text { M2(tanah : }\end{array}$ & $0.87 \mathrm{a}$ & $5.82 \mathrm{a}$ & $14.30 \mathrm{a}$ & $26.41 \mathrm{a}$ & $34.81 \mathrm{a}$ & $42.16 \mathrm{a}$ & 46.89 a & 50.70 a \\
\hline $\begin{array}{l}\text { pasir : kompos, } \\
2: 1: 2)\end{array}$ & $0.88 \mathrm{a}$ & $8.66 \mathrm{~b}$ & $16.04 \mathrm{a}$ & $31.51 \mathrm{a}$ & $40.58 \mathrm{a}$ & $48.51 \mathrm{a}$ & $52.38 \mathrm{a}$ & $55.16 \mathrm{a}$ \\
\hline $\begin{array}{l}\text { M3(tanah : } \\
\text { pasir : kompos, } \\
\text { 2:2:1) }\end{array}$ & $0.86 \mathrm{a}$ & $7.21 \mathrm{ab}$ & $15.80 \mathrm{a}$ & $31.04 \mathrm{a}$ & $40.82 \mathrm{a}$ & 44.99 a & 49.92 a & $53.01 \mathrm{a}$ \\
\hline \multicolumn{9}{|l|}{$\mathrm{ZPT}(\mathrm{Z})$} \\
\hline $\mathrm{Z} 1(1.5 \mathrm{ml} / \mathrm{l})$ & $0.77 \mathrm{a}$ & $7.38 \mathrm{a}$ & $14.75 \mathrm{a}$ & $31.24 \mathrm{a}$ & $36.47 \mathrm{a}$ & $43.83 \mathrm{a}$ & $47.65 \mathrm{a}$ & $50.41 \mathrm{a}$ \\
\hline $\mathrm{Z} 2(2 \mathrm{ml} / \mathrm{l})$ & $0.84 \mathrm{a}$ & $6.33 \mathrm{a}$ & $16.12 \mathrm{a}$ & $27.37 \mathrm{a}$ & $40.18 \mathrm{a}$ & $47.44 \mathrm{a}$ & $51.83 \mathrm{a}$ & $55.37 \mathrm{a}$ \\
\hline $\mathrm{Z} 3(2.5 \mathrm{ml} / \mathrm{l})$ & $0.99 \mathrm{a}$ & $7.98 \mathrm{a}$ & $15.28 \mathrm{a}$ & $30.36 \mathrm{a}$ & $39.55 \mathrm{a}$ & $44.39 \mathrm{a}$ & $49.70 \mathrm{a}$ & $53.08 \mathrm{a}$ \\
\hline
\end{tabular}

Keterangan : Angka-angka yang diikuti dengan huruf yang sama pada baris dan kolom yang sama tidak berbeda nyata pada uji Duncan $(\alpha=0,05)$.

Hasil uji DMRT 5\% (Tabel 2) pada perlakuan komposisi meida tanam menunjukkan perbedaan yang nyata pada perlakuan M3 (tanah + pasir +kompos 2:2:1) dengan rata rata tinggi tanaman pada umur 21 HST $8,66 \mathrm{~cm}$. hal diduga menyediakan unsur hara yang lebih baik dari pada perlakuan lain. Penambahan kompos pada media akan mampu memperbaiki sifat fisik serta menjadikan tanah menjadi gembur. Mikroorganisme dalam kompos akan mempercepat proses dekomposisi sehingga akan lebih cepat disediaakan untuk tanaman, selain itu aktifitas mikroorganisme pada media akan menghasilkan $\mathrm{CO} 2$ yang dapat digunakan untuk fotosintesis tanaman untuk menunjang pertumbuhan.

Hal ini sesuai dengan Rosmarkam dan Yuono (2002), pemberian komos pada tanah dapat memperbaiki sifat fisik tanah menjadikan tanah menjadi gembur dan mudah diolah. Tanah yang gembur akan mempermudah perkembangan akar serta mensuplai ketersediaan oksigen (Hanum, 2008). Setyorini et al (2010) menambahkan didalam kompos terdapat mikroorganisme pengurai yang dapat menghasilkan senyawa polisakarida yang menjadikan tanah gembur serta adanya hifa yang dpat mengikat partikel tanah, hal ini memungkinkan aerasi dan drainase tanah lebih baik sehingga proses fisiologis diakar akan lancar. Nurwardani (2008) menambahkan oksigen pada tanah dibutuhkan oleh jasad renik tanah untuk menguraikan bahan organik menjadi unsur hara unsur hara yang diperlukan tanaman. 
Hal ini sesuai dengan Rosmarkam dan Yuono (2002), pemberian komos pada tanah dapat memperbaiki sifat fisik tanah menjadikan tanah menjadi gembur dan mudah diolah. Tanah yang gembur akan mempermudah perkembangan akar serta mensuplai ketersediaan oksigen (Hanum, 2008). Setyorini et al (2010) menambahkan didalam kompos terdapat mikroorganisme pengurai yang dapat menghasilkan senyawa polisakarida yang menjadikan tanah gembur serta adanya hifa yang dpat mengikat partikel tanah, hal ini memungkinkan aerasi dan drainase tanah lebih baik sehingga proses fisiologis diakar akan lancar. Nurwardani (2008) menambahkan oksigen pada tanah dibutuhkan oleh jasad renik tanah untuk menguraikan bahan organik menjadi unsur hara unsur hara yang diperlukan tanaman.

Setiap tanaman memiliki sarat tumbuh yang berbeda untuk menunjang ertumbuhannya. Menurut Suhartanto et al (2012) tanaman pisang membutuhkan suhu berkisar $26^{\circ} \mathrm{C}-28^{\circ} \mathrm{C}$, Menurut Suhartanto et al (2012) tanaman pisang memerlukan tanah yang berdrainase baik dengan kandungan humus yang tinggi. Putra et al (2014) tanaman pisang menghendakai media dengan struktur remah dengan keseimbangan perbandingan antara bahan padat dan runag berpori.

Secara umum suhu yang sedang yang dekat dengan suhu optimum akan dikehendaki oleh tanaman tertentu. Suhu yang sedang akan dapat memperbaiki lengas tanah serta membantu aerasi tanah. Keaneragaman ini memungkinkan memberikan keuntungan secara langsung bagi pertumbuhan tanaman (Nurwandani, 2008). Jati (2013) mengatakan bahwa suhu yang optimum memungkinkan tanaman akan tumbuh dengan subur. Pada saat media berada pada suhu minimum akan menurunkan ketersediaan unsur zat hara tanaman, terutama zat hara yang ketersediaannya ditentukan oleh kegiaatan mikroba.

Di dalam tanah terdapat unsuh hara mikro maupun makro yang di butuhkan oleh tanaman. Serta sebagai tempat habitat mikroorganisme yang dapat membantu menyediakan unsur hara serta zat-zat adiktif (pemacu tumbuh, proteksi) untuk menunjang produktifitas tanaman (Nurwardani, 2008). Tanah dengan drainase yang baik akan mencegah air menggenang, mengatur suhu serta menjaga kelembapan tanah sesuai dengan kebutuhan tanaman serta menjaga tanah dari perkembangan berbagai patogen yang merugikan (Pandutama, et al 2003).

Tanah yang memiliki kandungan bahan organik atau kadar liat yang tinggi akan memiliki KTK lebih tinggi dari pada tanah dengan bahan organik rendah atau tanah berpasir (Mustafa, et al 2012). KTK tanah memiliki peran dalam meningkatkan kesuburan tanah. Tanah yang memiliki KKT tinggi akan mampu menjerap dan menyediakan unsur hara lebih baik dari pada tanah yang memiliki KTK rendah (Pandutama, et al 2003)

Penambahan bahan organik pada tanah akan mampu meningkatkan kemampuan tanah dalam memegang air dan KTK tanah sehingga mengurangi kemungkinan tercucinya hara dari tanah. Hal ini disebabkan karena bahan organik akan mampu memegang hara tanah dengan kuat dan melepaskan kembali sehingga tersedia bagi tanaman (Nurwardani, 2008).

Mustafa et al (2012) mengatakan kompos memiliki kapasitas tukar kation (KTK) yang lebih tinggi dari pada lempung sebesar 3-10 kali, sehingga menyediakan hara mikro maupun makro lebih lama pemberian kompos dalam jangka panjang dapat memperbaiki $\mathrm{pH}$ pada tanah masam. Tanah yang gembur akan mempermudah perkembangan akar serta mensuplai ketersediaan oksigen (Hanum, 2008). Nurwardani (2008) menambahkan 
oksigen pada tanah dibutuhkan oleh jasad renik tanah untuk menguraikan bahan organik menjadi unsur hara unsur hara yang diperlukan tanaman.

Rosmarkam dan Nasih (2002) mengatakan pemberian kompos dapat meningkatkan unsur hara makro maupun mikro walaupun dalam jumlah kecil, serta penambahan kompos dapat mempercepat proses dekomposisi karena didalam kompos mengandung berbagai mikroorganisme. Setyorini et al (2010) menambahkan mikroorganisme yang berada dalam kompos dapat menghasilkan hormon pertumbuhan yang memicu pertumbuhan akar, serta mikroorganisme yang berada dalam akar dapat menghasilkan gas $\mathrm{CO} 2$ yang dapat digunakan untuk fotosintesis tanaman sehingga pertumbuhan tanaman akan lebih baik.

Seperti penelitian yang dilakukan oleh Putra et al (2014) bahwa interaksi perlakuan komposisi media tanam tanah : sekam padi : kompos ( $2: 1: 2)$ dengan konsentrasi ZPT atonik $1,5 \mathrm{ml}$ liter - air berpengaruh nyata pada variabel total berat basah dan kering oven bibit pisang.

Penelitian yang dilakukan oleh Putri et al (2013) juga mengatakan bahwa media pasir yang dikombinasikan dengan media lain seperti tanah dan kompos dengan perbandingan tanah : pasir : kompos ( 10\%:20\%: 70\%) pada pembibitan tanaman tebu menghasilkan nilai rerata diameter batang, jumlah daun, luas daun, bobot segar total tanaman dan bobot kering tanaman lebih tinggi dari perlakuan lain

\section{Panjang Akar}

Hasil analisis sidik ragam (ANOVA) taraf 5\% dengan Rancangan Acak Kelompok (RAK) menunjukkan bahwa interaksi antara komposisi media tanam (M) dengan konsentrasi Zat Pengatur Tumbuh (ZPT) tidak berpengaruh nyata pada variabel panjang akar tanaman pisang. Komposisi media tanam (M) tidak memberikan pengaruh nyata terhadap variabel panjang akar tanaman pisang pada masing masing perlakuan. Konsentrasi ZPT $(\mathrm{Z})$ berpengaruh nyata terhadap variabel panjang akar tanaman pisang pada masing masing perlakuan.

Tabel 3. Pengaruh Komposisi Media Tanam (M) Dan Konsentrasi Zat Pengatur Tumbuh (Z) Terhadap panjang akar Tanaman Pisang..

\section{Perlakuan}

\section{Panjang akar (cm)}

Media (M)

M1 ( tanah : pasir : kompos, 2:1:1)

30.69 a

M2 ( tanah : pasir : kompos, 2:1:2)

$31.68 \mathrm{a}$

M3 (tanah : pasir : kompos, 2:2:1)

29.09 a

ZPT (Z)

\begin{tabular}{ll}
$\mathrm{Z} 1(1.5 \mathrm{ml} / \mathrm{l})$ & $31.43 \mathrm{ab}$ \\
$\mathrm{Z} 2(2 \mathrm{ml} / \mathrm{l})$ & $34.97 \mathrm{~b}$ \\
$\mathrm{Z} 3(2.5 \mathrm{ml} / \mathrm{l})$ & $27.61 \mathrm{a}$ \\
\hline
\end{tabular}

Keterangan : Angka-angka yang diikuti dengan huruf yang sama pada baris dan kolom yang sama tidak berbeda nyata pada uji Duncan $(\alpha=0,05)$. 
Hasil uji DMRT 5\% (Tabel 3) menunjukkan bahwa perlakuan media tidak menunjukkan perbedaan yang nyata pada variabel panjang akar pada akir pengamatan. Perlakuan ZPT menunjukkan perbedaan yang nyata pada perlakuan Z2 (2 ml/l) dengan rata rata panjang akar $34.97 \mathrm{~cm}$. Hasil uji regresi 5\% pada perlakuan konsentrasi ZPT terdapat berbeda nyata pada variabel panjang akar. Disajikan pada gambar 1

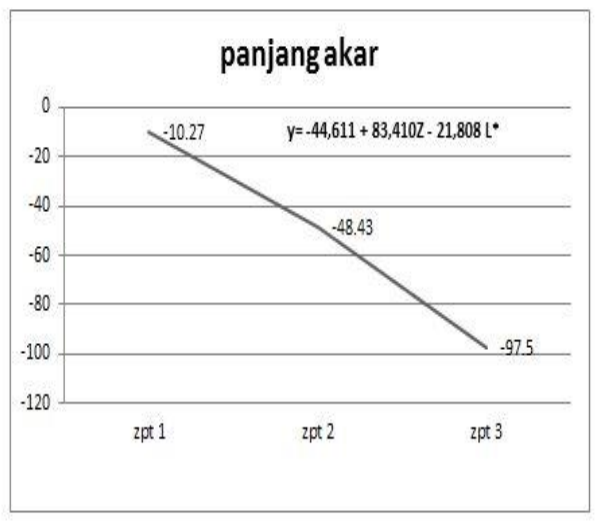

\section{Gambar 1. Grafik Rata-Rata pengaruh Konsentrasi ZPT Terhadap Panjang Akar}

Dari grafik di atas menunjukkan bahwa pemberian perlakuan ZPT dengan konsentrasi yang lebih tinggi mengakibatkan panjang akar semakin rendah, pemberian ZPT dengan konsentrasi 1,5 ml/l memberikan rerata panjang akar terbaik. Hal ini diduga karena pemberian ZPT atonik $2 \mathrm{ml} / \mathrm{l}$ mengandung hormon auksin yang dapat menstimulasi pembelahan sel, auksin yang diberikan pada tanaman mempengaruhi pembelahan dan pemanjangan sel tanaman. Menurut Satria (2011). Pemberian ZPT secara tepat dapat mempercepat perakaran, seperti halnya hormon auksin dapat merangsang pertumbuhan dan perakaran tanaman. Didalam tanaman terdapat hormon tumbuh yaitu senyawa organik dalam jumlah sedikit, maka perlu penambahan hormon sintesis dari luar. Hormon sintesis atau zat pengatur tumbuh berfungsi untuk merangsang pertumbuhan akar, tunas dan lainnya (Widiastoety, 2014).

Auksin merupakan salah satu senyawa zat pengatur tumbuh bagi tanaman dapat mendukung perpanjangan sel. Meristem tunas apikal adalah tempat utama sintesis auksin. Pada saat auksin bergerak dari ujung tunas ke bawah ke daerah perpanjangan sel, maka hormon auksin mengstimulasi pertumbuhan sel, mungkin dengan mengikat reseptor yang dibangun di dalam membran plasma (Dewi, 2008). Rineksane (2005) mengatakan Pertumbuhan pada akar dipengaruhi oleh hormon auksin yang dikandung dalam akar dan ditranslokasikan ke akar untuk mendorong pertumbuhan akar tanaman. Pamungkas (2008), menambahkan auksin pada tanaman berperan dalam merangsang pertumbuhan kalus, pembesaran sel dan pertumbuhan akar, serta morfogenesis terutama berinteraksi dengan sitokinin. Pemberian zat pengatur tumbuh pada akar tidak hanya mempengaruhi panjang akar tetapi juga memperbanyak akar lateral (Nisa dan Rodinah, 2005).

Konsentrasi auksin optimum dalam merangsang pertumbuhan akar, kuncup dan daun mempunyai kisaran yang berbeda beda, biasanya pada konsentrasi tertentu antara 10-8 M sampai 10-4 M (Widiastoety, 2014). pada konsentrasi yang lebih tinggi auksin akan menghambat perpanjangan sel dengan memproduksi hormon yang berfungsi sebagai inhibitor pada perpanjangan sel (Rineksane, 2005). Sama halnya seperti yang dikatakan 
oleh Dewi (2008) bahwa auksin akan menghambat perpanjangan sel, mungkin dengan menginduksi produksi etilen, yaitu suatu hormon yang pada umumnya berperan sebagai inhibitor pada perpanjangan sel.

Antonik salah satu hormon tumbuhan yang mengandung auksin sintetik. Sunarlim et al (2011) mengatakan kandungan dalam atonik berupa natrium orthophenol $(0,2 \%)$, natrium para nitrophenol $(0,3 \%)$, natrium 5-nitroguaiacolat $(0,1 \%)$, dan 2,4 dinitrophenolat $(0,01 \%)$. Pada dasarnya antonik berperan dalam merangsang pertumbuhan akar tanaman, meningkatan keluarnya kuncup, serta mengefektifkan penyerapan unsur hara (Sunarlim, et al 2011). Suprapto, (2004) menambahkan auksin sintetik yang terkandung pada atonik mendorong terjadinya pembelahan sel dengan cara mengurangi tekanan pada dinding sel karena membran plasma dinding sel menjadi longgar akibat pengaktifan pompa ion pada membrane plasma, sehingga air dapat mudah masuk ke dalam sel dan terjadi pembesaran dan perpanjangan sel.

Seperti penelitien yang dilakukan oleh Asmarawati dan Ahmad, (2011) bahwa perlakuan perendaman belahan bonggol bit pisang dengan ZPT atonik memberikan pengaruh nyata pada variabel tinggi tanaman dibandingkan dengan perlakuan lainnya. Penelitian lain yang dilakukan oleh Abdulrahman (2013) bahwa perlakuan perendaman pada atonik dengan konsentrai $2 \mathrm{ml} / \mathrm{l}$ air memberikan pengaruh nyata pada pertumbuhan dan hasil jagung semai.

\section{KESIMPULAN}

Berdasarkan hasil penelitian mengenai pengaruh komposisi media tanam dan konsentrasi ZPT pada perbanyakan pisang mas dapat disimpulkan sebagai berikut :

1. Tidak terdapat interaksi antara perlakuan komposisi media tanam dan konsentrasi ZPT terhadap perbanyakan pisang mas metode belah bonggol.

2. Konsentrasi ZPT terbaik adalah $2 \mathrm{ml} / \mathrm{l}$ air.

\section{DAFTAR PUSTAKA}

Abdulrahman, I . 2013. Pengaruh Zat Pengatur Tumbuh Atonik dan Siapton Terhadap Pertumbuhan dan Hasil Tanaman Jagung Semi (Zea mays L.)

Asmarawati, M Dan Ahmad, B. 2011. Pengaruh Rooton F dan Atonik terhadap Pertumbuhan Bibit Pisang (Musa paradisiacu L.) pada Beberapa Media Tanam. Fakultas Pertanian Universitas PGRI Yogyakarta AcroUPY Volume 3, Nomor 1. Hal 21-29.

Hanum C. 2008. Teknik budidaya tanaman jilid 3 untuk SMA. Buku Ajar Untuk Sekolah Menengah Kejuruan. Direktorat pembinaan sekolah menengah kejuruan, Jakarta.Hal 1-243.

Husniati, K. 2010. Pengaruh Media Tanam Dan Konsentrasi Auksin Terhadap Pertumbuhan Stek Basal Daun Mahkota Tanaman Nenas (Ananascomosus L. Merr) cv. Queen. Skripsi Pemuliaan Tanaman dan Teknologi Benih Fakultas Pertanian Institut Pertanian Bogor.

Jati, G.E.A.S. 2013. Pengaruh Media Tanam dan Zat Pengatur Tumbuh Sitokinin (Ba) Terhadap Perbanyakan Tunas Pisang Raja Bulu (Musa paradisiaca L. ) Dari 
Cacahan Bonggol. Skripsi Departemen Agronomi dan Hortikultura Fakultas Pertanian Institut Pertanian Bogor.

Kementrian Pertanian Holtikultura. 2014. Statistik produksi hortikultura. Direktorat Jendral Hortilkultura, Kementrian Pertanian, Jakarta. hal. 29-34

Mulyanti, N. et al. 2008. Teknologi budidaya pisang. Balai pengkajian teknologi pertanian lampung, Bandar Lampung. hal 1-7

Mustafa M et al 2012. Dasar dasar ilmu tanah. Hibah Penulisan Buku Ajar. Jurusan Ilmu Tanah Fakultas pertanian universitas hasanuddin makassar. Hal 1-164.

Nisa, C. dan Rodinah. 2005. Kultur Jaringan Beberapa Kultivar Buah Pisang (Musaparadisiaca L.) Dengan Pemberian Campuran NAA dan Kinetin. BIOSCIENTIAE Vol 2, No 2, Hal 23-36.

Nurwardani P. 2008. Teknik pembibitan tanaman dan produksi benih jilid 1 untuk SMK. Buku Ajar Untuk Sekolah Menengah Kejuruan. Direktorat Pembinaan Sekolah Menengah Kejuruan, Jakarta. Hal 1-364.

Pamungkas S. 2008. Pengaruh konsentrasi NAA dan BAP terhadap pertumbuhan tunas eksplan tanaman pisang Cavendish (Musa paradisiac L.) melalui kultur in vitro. Gontor AGROTECH Science Journal. Vol.2 No. 1. Hal 31-45.

Pandutama M et al. 2003. Dasar dasar ilmu tanah. Buku Ajar. Jurusan Ilmu Tanah Fakultas Pertanian Universitas Jember.

Prabawati S et al. 2008. Teknologi paska panen dan teknik pengolahan buah pisang. Balai besar penelitian dan pengembangan paska panen pertanian. Hal 5-10

Putra, A.A.G. et al. 2014. respon bibit pisang (musa sapientum fixa lacte ) pada variasi komposisi media tanam dan zpt atonik. Fakultas Pertanian Universitas Tabanan Bali, GaneÇ Swara Vol. 9 No.1 hal 156 -162.

Rahayu, A.A.D dan Septiantina, D.R. 2016. Pengaruh Beberapa Jenis Zat Pengatur Tumbuh Terhadap Pertumbuhan Stek Batang Bidara Laut (Strychnos ligustrina Bl.). Jurnal Perbenihan Tanaman Hutan. Vol.4 No.1. Hal 25-31.

Rineksane, I.A., 2005. Pengaruh Lama Perendaman Biji dalam Auksin terhadap Perkecambahan dan Perturnbuhan Akar Manggis. AgTUMY Jurnal Ilmu - Ilmu Pertan ian. Fakultas Pertanian Universitas Muhammadiyah Yogtakarta. Vol.8 No. 2. Hal 83-9 1.

Rosmarkam A dan Nasih.W.Y. 2002. Ilmu kesuburan tanah. Kanikus. Yogyakarta. Hal 160.

Santoso J. 2012. Produksi benih pisang dari rumpun in situ secara konvensional.http//balitbu.litbang.deptan.go.id. diakses 15 Juli 2017.

Setyorini D et al. 2010. Pupuk organik dan hayati. Balai pustaka . Hal 11-40

Suhartanto et al. 2012. Teknologi sehat budidaya pisang dari benih sampai paska panen. Pusat kajian hortikultura tropika. Bogor. hal 9-14. 
Fuad Ardianto\&Sutiah, 2017. Respon Pertumbuhan Bibit Pisang Mas (Musa acuminate

Sunarlim N et al. 2011. Perlakuan benih dan perendaman dengan atonik pada perkecambahan benih dan pertmbuhan tanaman semangka non biji (citrullus vulgaris schard L.). Jurnal Agroteknologi, Vol. 2 No. 2. Hal 29-32.

Suprapto, A. 2004. Auksin : zat pengatur tumbuh penting meningkatkan mutu stek tanaman. Vol. 21, No. I. Hal 81-90

Supriana, I et al. 2015. Pengaruh Sumber Bonggol dan Media Tanam pada Pembibitan Tanaman Pisang Kayu (Musa paradisiaca L.cv.Kayu). E-Jurnal Agroekoteknologi Tropika Vol. 4, No. 2, Hal 124-134.

Widiastoety, D. 2014. Pengaruh Auksin dan Sitokinin terhadap pertumbuhan planlet anggrek moroka. J. Hort. 24(3). Hal 230-238. 